\title{
Sexual transmission of Zika virus: what is the issue for awareness?
}

\author{
Beuy Joob $^{1}$, Viroj Wiwanitkit ${ }^{2,3}$ \\ ${ }^{1}$ Sanitation 1 Medical Academic Centre, Bangkok, Thailand \\ ${ }^{2}$ Hainan Medical University China (Visiting Professor) \\ ${ }^{3}$ Dr DY Patil University, India (Honorary Professor)
}

Zika virus infection is the present global public health issue. For the non-vector borne transmission, it becomes the new topic in medicine. When a disease can be transmitted by more than one common mode of transmission, the control of the infection becomes very difficult. The sexual transmission of Zika virus has been mentioned for a few months with some sporadic case reports. The counteraction to the sexual transmission of Zika virus is an interesting issue. As Kuna and Gajewski [1] mentioned, there are many suggestions for prevention. Several actions are relating to safe sex and use of contraception [1]. Nevertheless, there are also many other issues for awareness.

First, the effectiveness of the safe sex against sexual transmission of Zika virus is still unknown. The standard condom can or cannot prevent the virus penetration has to be studied. Considering the nanostructure of virus, the size of virus is about $40 \mathrm{~nm}$ which is significantly smaller than that of HIV virus, of which, condom can be successfully used for prevention of viral penetration from contaminated semen across condom pore to the female genital tract. It seems that the most reliable and effective way for safe sex is abstinence.

Second, since there are many reports on the occurrence of Zika virus in semen, the safety of donated semen in semen bank has to be checked. This is also a big topic is reproductive assisted technology [2].

Third, using of contraception might be a solution for prevention of unwanted abnormal foetus. But it cannot prevent the mother or the pregnant from the clinical problems due to infection, which might range from mild acute febrile illness to severe infection with many post infection complications, especially for neurological deficit.

Finally, although safe sex and contraception is applied, the transmission of the disease can still occur via mosquito borne transmission and there are also other new possible modes of transmissions such as blood transfusion [3] and organ transplantation [4].

\section{REFERENCES}

1. Kuna A, Gajewski M. Prevention of sexual transmission of Zika virus. Int Marit Health 2016; 67: 179-180.

2. Gornet ME, Bracero NJ, Segars JH. Zika virus in semen: what we know and what we need to know. Semin Reprod Med 2016; 34: 285-292.

3. Jimenez A, Shaz BH, Bloch EM. Zika virus and the blood supply: what do we know? Transfus Med Rev 2016 Aug 9. doi: 10.1016/j. tmrv.2016.08.001. [Epub ahead of print].

4. Nogueira ML, Estofolete CF, Terzian AC et al. Zika virus infection and solid organ transplantation: a new challenge. Am J Transplant 2016 Sep 15. doi: 10.1111/ajt.14047. [Epub ahead of print]. 